\title{
A note on the Early Cretaceous biostratigraphy (foraminifera) of borehole 49/24-1 (Shell/Esso) in the southern North Sea
}

\author{
S. CRITTENDEN \\ Paleoservices Ltd., Sandown Road, Watford WD 2 4XA. England
}

\begin{abstract}
Borehole 49/24-1 (Shell/Esso), which is the reference borehole for the Lower Cretaceous Cromer Knoll Group in the southern North Sea, is subdivided lithostratigraphically and biostratigraphically. The resulting stratigraphy is briefly compared to onshore U.K. outcrop and borehole sections of comparable age and lithofacies. The regional stratigraphical implications for the correlation of offshore and onshore sections of Lower Cretaceous (Albian) strata are briefly discussed.
\end{abstract}

\section{INTRODUCTION}

Borehole 49/24-1 (Shell/Esso) is the reference borehole section for the Lower Cretaceous Cromer Knoll Group of the British lithostratigraphical scheme in the southern North Sea (Rhys, 1974, 1975). The type section is borehole 48/22-2 (Burmah).

During a research study of the Early Cretaceous stratigraphy of blocks 49 and 44 of the British southern North Sea, data from borehole 49/24-1 were made available for study. Harris (1982), in a biostratigraphical study of the Albian strata of England and north west Europe, has previously examined the Early Cretaceous strata of borehole 49/24-1. Harris concluded that only strata of an Upper Albian age were present (Biozones 5a-6a of Hart, 1973; Biozones 7ii-9iii of Price, 1977b); top $M$. inflatum and $S$. dispar Ammonite Biozones). The present author has re-examined the sieve fraction residues (washed samples) for lithology and foraminifera, and the faunal slides (unsorted) of Harris (foraminifera and ostracods). These data have been used in the light of additional research to reinterpret the Early Cretaceous strata in borehole 49/24-1. The location of borehole 49/ 24-1 and the other studied boreholes is shown in Fig. 1.

\section{LITHOSTRATIGRAPHY}

Crittenden (1982) has demonstrated the ease with which a correlation may be made, by lithostratigraphical and electric log data, of the Lower Cretaceous strata in the southern North Sea Basin using either the British scheme (Rhys, 1974, 1975) or the Dutch scheme (N.A.M. \& R.G.D., 1980). This is illustrated in Fig. 2.

In borehole 49/24-1 two lithostratigraphical subdivisions of the Lower Cretaceous are recognised; Upper Holland Marl Member (Red Chalk Formation) and the underlying Middle Holland Shale Member (Speeton Clay Formation (pars)). The lithostratigraphy (using lithology and electric log data) of borehole 49/24-1 has been previously described by Rhys (1974) and Crittenden (1982).

\section{BIOSTRATIGRAPHY}

There is an incomplete coverage of the Early Cretaceous section, by ditch cuttings samples, of borehole 49/24-1.

Due to the lack of samples, the Cenomanian/Albian boundary is not defined biostratigraphically but is picked lithologically at 4,243 feet (see Figs. 2 and 3). From other borehole evidence in the southern North Sea Basin the stage boundary lies either within the basal section of the overlying Texel Chalk (Chalk Group) or within the topmost part of the Upper Holland Marl Member (Red Chalk Formation). For convenience, a pragmatic approach is necessary and the electric $\log$ / lithological boundary may be taken as the Cenomanian/ Albian boundary (e.g. Burnhill \& Ramsay, 1981, fig. 4, borehole $24 / 1 \mathrm{a}-8$ ).

The first five downhole samples examined (see Fig. 3) in borehole 49/24-1 within the Early Cretaceous each contain a light red brown coloured foraminiferal fauna. This is a characteristic of the Upper Holland Marl Member (Red Chalk formation) in block 49 and in other regions of the southern North Sea and is in stark contrast to the white coloured faunas of the overlying chalk. There is a marked colour change at sample interval 4,340-4,350 ft where specimens of Valvulineria spp., Gavelinella gr. intermedia (Berthelin) and A renobulimina macfadyeni (Cushman) are a grey-white colour quite distinct from the red brown above. A further, but subtle, colour change in the fauna is noted at $4,390-4,400 \mathrm{ft}$ (and below) where the fauna is a dark reddish brown colour, different to that above in the Upper Holland Marl Member (Red Chalk Formation). 


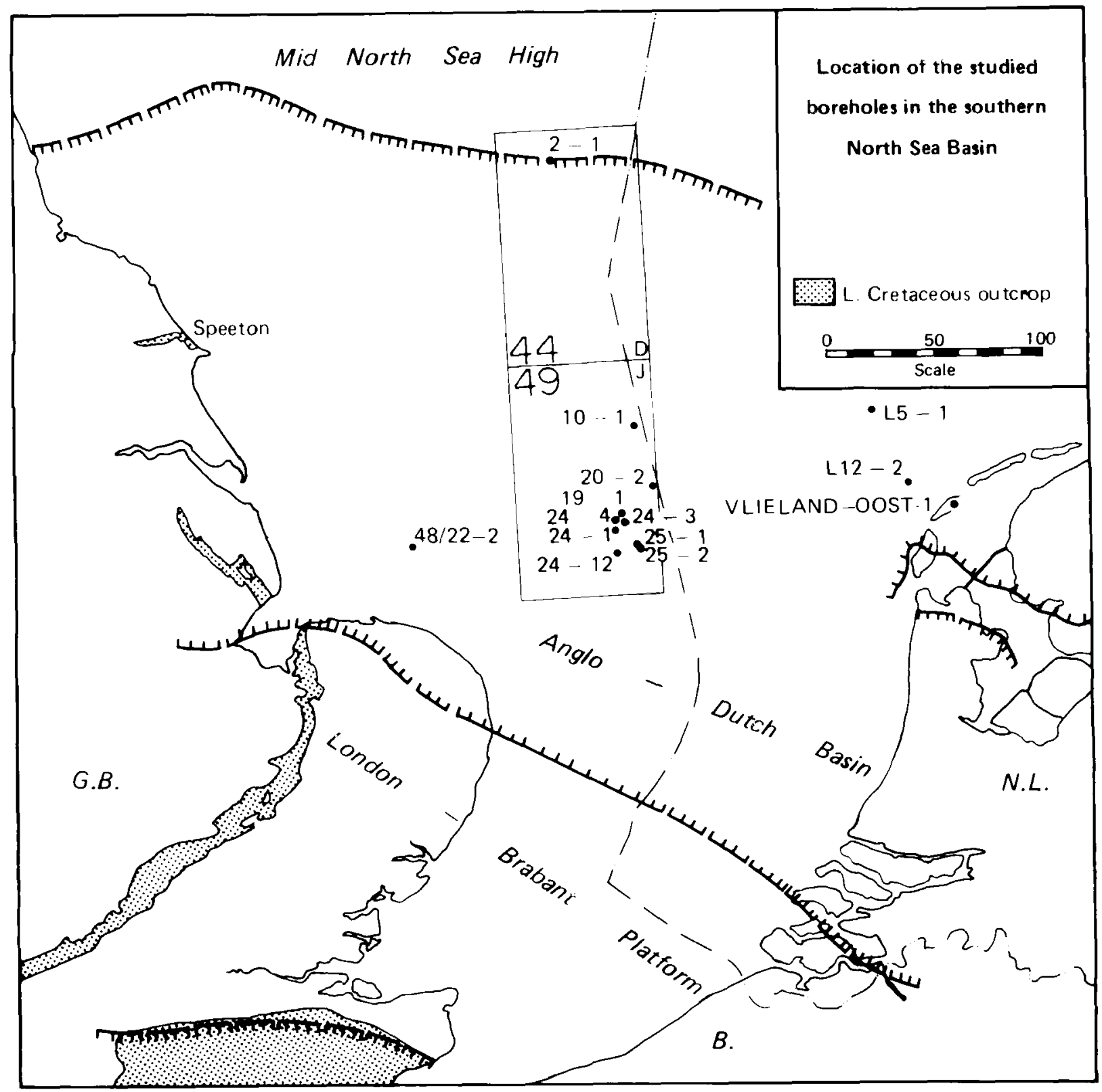

Fig. 1. Location of the studied boreholes in the southern North Sea Basin.

\section{Planktonic Foraminifera}

The planktonic foraminiferal fauna is dominated by the Hedbergella delrioensis (Carsey) - Hedbergella infracretacea (Glaessner) - Hedbergella brittonensis (Loeblich \& Tappan) plexus. Members of this plexus become larger in size up the borehole section through the Early Cretaceous. This size increase has been noted by Price (1977a) and Carter \& Hart (1977) in the Albian of north west Europe. Large high-spired forms are attributable to $H$. brittonensis (= Whiteinella brittonensis of authors, e.g. Robaszynski \& Caron, 1979) which is a characteristic species of the Late Albian and Early
Cenomanian. Small, high-spired forms are attributable to $H$. infracretacea. Price (1977a) has discussed this plexus and its stratigraphical use in the Albian of north west Europe in some detail and it is not reiterated here.

$H$. planispira (Tappan) is a distinctive species which in north west Europe is present throughout the greater part of the late Early Cretaceous (Bartenstein, 1965 ; Carter \& Hart, 1977; Price, 1977a; Harris, 1982).

H. simplex (Morrow) is a Late Albian-Cenomanian species in north west Europe (Robaszynski \& Caron, 1979). In sample interval $4,290-4,300 \mathrm{ft}$ this species is a distinctive light red brown colour and has probably 
caved from the unsampled uppermost Upper Holland Marl Formation (Red Chalk Formation).

Globigerinelloides bentonensis (Morrow) is an important index planktonic species as its occurrence in large numbers (flood horizons) is indicative of the Late Albian in north west Europe. Floods of this species have been recorded from horizons in Late Albian sediments of southern England, the central North Sea, Northern France and Germany (Hart, 1973; Carter \& Hart, 1977; Price 1977b; Burnhill \& Ramsey, 1981 ; Harris, 1982). It is encountered rarely in the Middle Albian and it ranges up into the Cenomanian.

The planktonic foraminiferal fauna indicates a Late Albian age for the calcareous mudstones of the Upper Holland Marl Member (Red Chalk Formation) of borehole 49/24-1 and is very similar to Late Albian planktonic faunas recorded from onshore sections in north west Europe.

\section{Benthonic Foraminifera}

The benthonic foraminiferal fauna is both diverse and numerous and is important for dating the Lower Cretaceous strata in this borehole. Arenobulimina chapmani Cushman, A. frankei Cushman, Eggerellina mariae ten Dam and Quinqueloculina antiqua (Franke) are, according to Bartenstein (1976a, b, c; 1977; 1978a, b; 1979), Carter \& Hart (1977), Price (1977b) and Harris (1982), important members of the Late Albian benthonic foraminiferal fauna in north west Europe. This species association suggests a Late Albian age for the Upper Holland Marl Member (Red Chalk Formation). This age is supported by the occurrence of Gavelinella cenomanica (Brotzen), Gavelinella gr. intermedia
(Berthelin) and Valvulineria spp. (including $V$, berthelini Janin, $V$. angulata Jannin, $V$. loetterli (Tappan) and $V$. praestans Jannin) which are recorded together in the Late Albian of north west Europe by various authors (e.g. Price, 1977b; Magniez-Jannin, 1975).

Arenobulimina macfadyeni (Cushman) and Hoeglundina chapmani (ten Dam) are Middle Albian species (first appearance downhole) in north west Europe (Carter \& Hart, 1977; Price, 1977b; Harris, 1982). This suggests an Early to Middle Albian age for the Middle Holland Shale Member (Speeton Clay (pars)) in borehole 49/24-1.

Haplophragmoides nonioninoides (Reuss) and Glomospira gr. gaultina (Berthelin) appear as a flood in sample interval 4,390-4,400 ft. This increase in agglutinated benthonics is a facies event and is probably associated with the diachronous Albian transgression phases (whether Middle or Early Albian in age) in north west Europe (e.g. Hecht, 1938; Price, 1977b; Ziegler, 1982; Rawson \& Riley, 1982). This event is depicted by the lithology and electric log character near the base of the Lower Cretaceous sections in boreholes 49/24-1; 49/24-4 and 49/24-3, as a coarse clastic horizon (see Fig. 2).

The occurrence of $G$. baltica Brotzen in the Middle Holland Shale is probably a result of caving from the Upper Holland Marl Member.

Notable species absent from the fauna recovered from borehole 49/24-1 are Osangularia schloenbachi (Reuss), which in the southern North Sea Basin is a characteristic of the Late Aptian and Early to Middle Albian (Crittenden, 1983) and Conorboides lamplughi (Sherlock), a species characteristic of the Early and

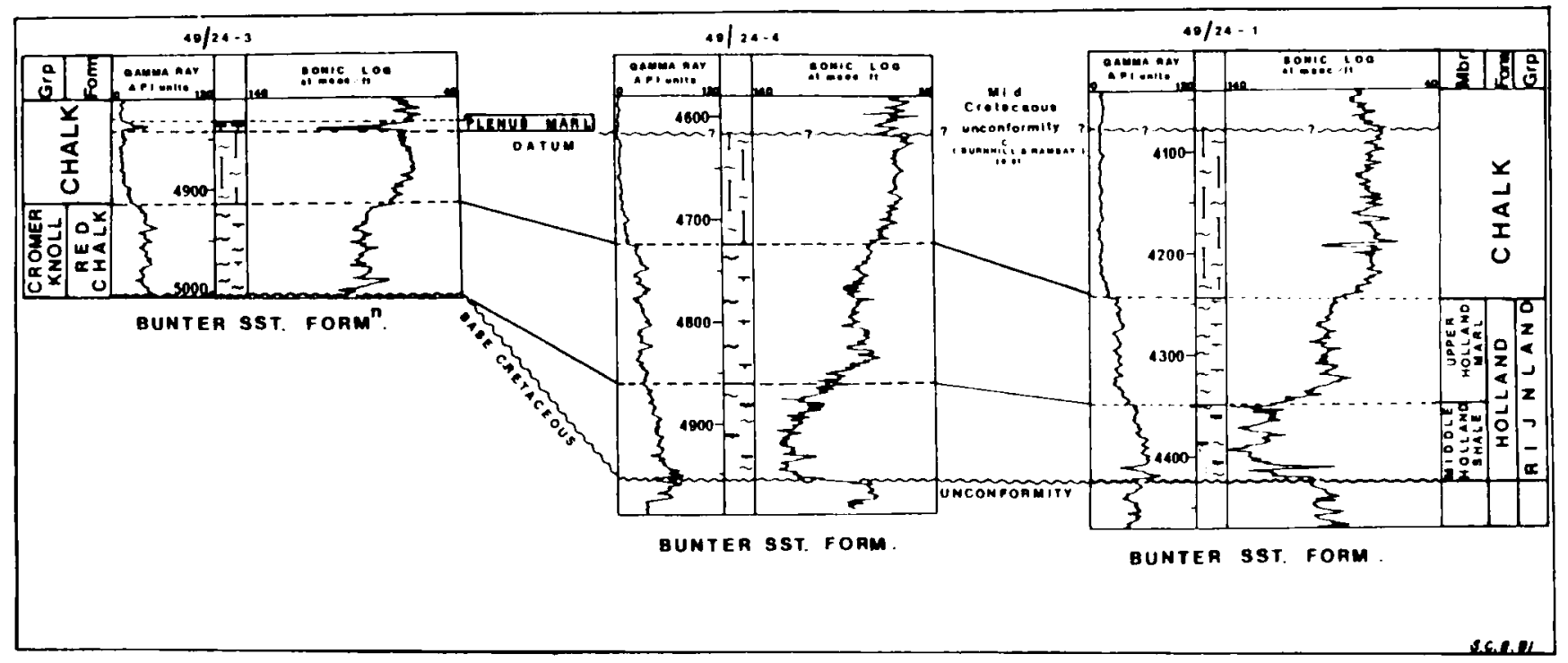

Fig. 2. The lithostratigraphic correlation of boreholes $49 / 24-3,49 / 24-4$ and $49 / 24-1$ in the southern North Sea Basin using both the Dutch and British schemes. 
comparison with faunas from onshore locations adjacent Middle Albian (Hart et al., 1981). A very important species which is used by various authors to denote the Early and Middle Albian in the North Sea is "Globigerinelloides?" gyroidinaeformis Moullade (Burnhill \& Ramsay, 1981). This species was not found in the samples studied from borehole 49/24-1, and is not particularly common in the other studied boreholes from block 49 (Crittenden, unpub. research). These three species probably owe their absence in borehole 49/24-1 to the small sample size and to the large sample interval (they are present in some of the other studied boreholes in block 49).

\section{BIOSTRATIGRAPHICAL CONCLUSIONS FOR BOREHOLE 49/24 -1}

The nature of the samples (ditch cuttings) precludes a detailed dating of the studied section. The fauna in borehole 49/24-1 is not referred to the biozonations of Hecht (1938), Hart (1973), Carter \& Hart (1977) and Price (1977b). However, an age is assigned based upon to the southern North Sea Basin (Hecht, 1938; Hart, 1973; Carter \& Hart, 1977; and Price, 1977b).

Both the planktonic and benthonic faunas in borehole 49/24-1 indicate that the Upper Holland Marl Member (Red Chalk Formation) is Late Albian in age and that the Middle Holland Shale Member (Speeton Clay (pars)) is Early to Middle Albian in age (and perhaps Late Aptian).

The planktonic foraminifera are dominant in the Upper Holland Marl Member (Red Chalk Formation) while the benthonic foraminifera are dominant in the Lower Holland Shale Member (Speeton Clay (pars)) This same relationship has been noted by Price (1977b) and Magniez-Jannin (1975) for the Albian strata of north west Europe.

Due to lack of samples an age dating of the basal section of the Lower Cretaceous section in this borehole is tentative. However, the presence of Gavelinella brielensis Malapris-Bizouard and $G$. barremiana Bettenstaedt together, would suggest the presence of Aptian strata (Hart et al., 1981) in the interval 4,400$4,420 \mathrm{ft}$.

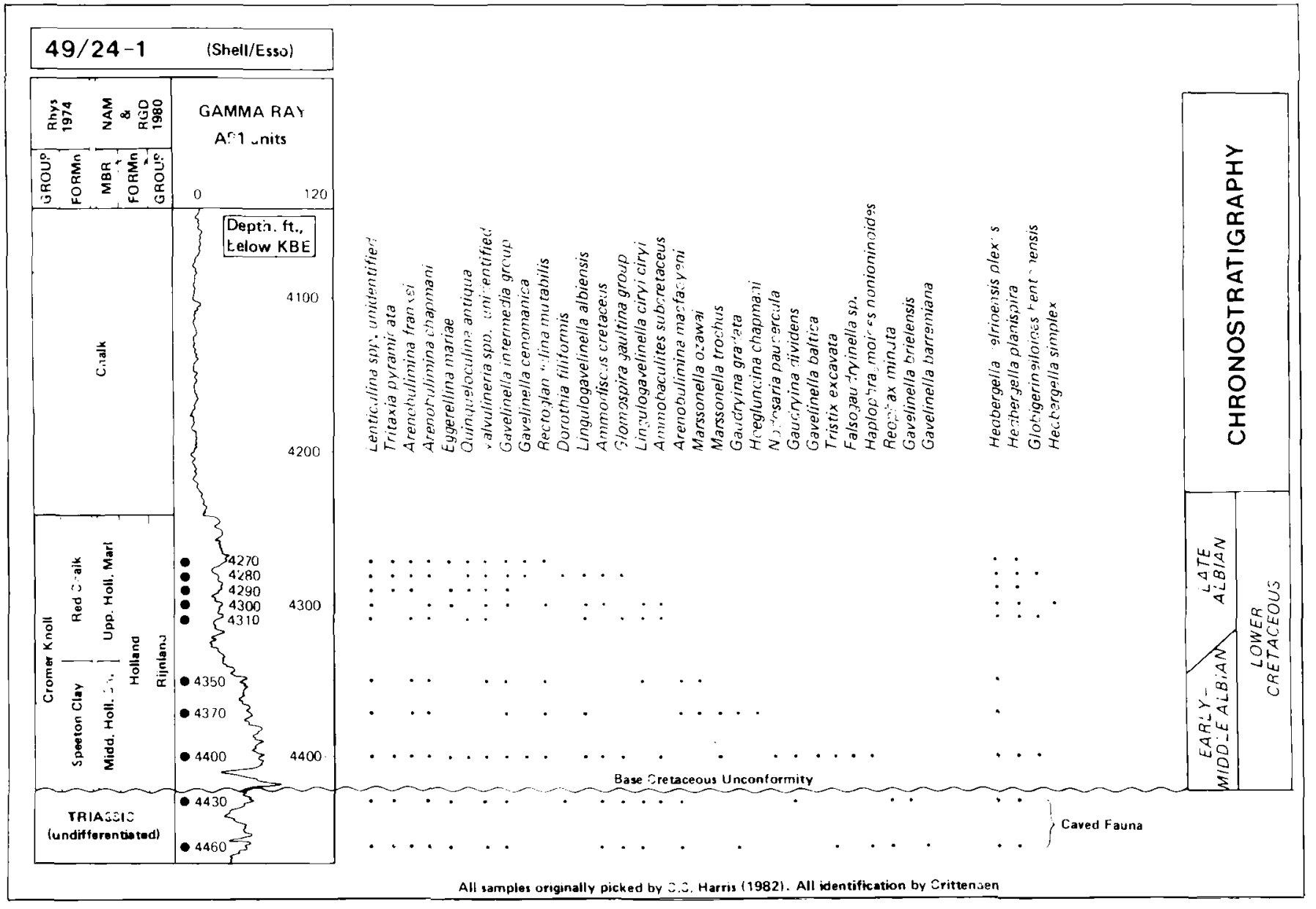

Fig. 3. Foraminiferal range chart for the Early Cretaceous of borehole 49/24-1. 
Gaudryina dividens Grabert is a species recorded from the lowermost Middle Albian to the top Early Aptian of north west Europe by Grabert (1959) and Bartenstein (op. cit.). The specimens of $G$. dividens from borehole 49/24-1 show an affinity to forms of the species illustrated by Grabert from the Upper Aptian (Grabert, 1959, table 1, figs. 3-5; table 2, figs. 16-27). However this Late Aptian age assignment has not been indicated on Fig. 3.

\section{STRATIGRAPHICAL DISCUSSION Offshore southern North Sea}

Borehole 49/24-1 correlates lithostratigraphically and biostratigraphically extremely well with other boreholes in block 49, and in adjacent areas, of the southern North Sea Basin (Crittenden, 1982). It is located on a structural high/fault block which, during the Early Cretaceous, underwent uplift and erosion (Glennie $\&$ Boegner, 1981). This has resulted in either the subsequent removal or non-deposition of pre-?Late Aptian/ Early Albian strata. The microfaunal evidence indicates that only a relatively thin veneer of ?Late Aptian and Albian sediments were deposited, near the base of which is a thin transgressive siltstone/sandstone horizon. Borehole 49/24-1 is a good illustration of the onlap of Lower Cretaceous sediments on to Cretaceous structural highs as a result of the late Early Cretaceous marine transgression (Day et al., 1981) and local tectonic activity (Glennie \& Boegner, 1981).

The gamma ray and sonic logs of a number of boreholes show the same feature at or near the base of the Middle Holland Shale Member (see figs. 3 and 4 in Crittenden, 1982). This siltstone/sandstone horizon may be correlated with the greensand intercalations at the base of the Middle Holland Shale Member in the Netherlands offshore and onshore (N.A.M. and R.G.D., 1980). These intercalations are thickest along the southern margin of the southern North Sea Basin and they rapidly shale out towards the depositional centres. In the west Netherlands Basin thicker developments of green, glauconitic, fine grained, basin margin sandstones and siltstones are termed the Holland Greensand member (N.A.M. and R.G.D., 1980), see Fig. 4. The Holland Greensand Member is Late Aptian to Early Albian in age in the Netherlands offshore (N.A.M. and R.G.D., 1980) and foraminiferal evidence suggests that this age range is valid for sandy horizons at the transgressive base of the Middle Holland Shale Member in some boreholes in the U.K. southern North Sea Basin (Crittenden, unpub. research, and borehole 49/24-1 this paper).

\section{Onshore United Kingdom}

The Winterborne Kingston borehole (Lat. $50^{\circ} 46.80^{\prime} \mathrm{N}$, Long. $2^{\circ} 13.02^{\prime} \mathrm{W}$ ) provides a very good example for a comparison with the offshore, of the electric log responses of the lithological units which make up the Albian strata onshore (Fig. 5). This is despite the large distance of the Winterborne Kingston borehole from the southern North Sea Basin.

The Plenus Marl is an easily recognised horizon in the Winterborne Kingston borehole and provides a marker horizon and datum for any lithological-electric log correlation. Unfortunately, this datum is absent in borehole 49/24-1 but it is present in adjacent boreholes in block 49 and other areas of the southern North Sea (Crittenden, 1982). Carter \& Hart (1977) have documented this datum across southern England from Buckland Newton in Dorset to Hunstanton in Norfolk.

The Winterborne Kingston borehole has been drilled at the western end of the Lower Cretaceous depositional basin (Wessex Basin or Southern Basin) in southern England where the Gault Clay and its sandy/conglomeratic base transgresses westward over folded and eroded earlier Cretaceous and Jurassic strata. Regional outcrop data illustrate the transgression; for example south of the London-Brabant Platform by the Lower Greensand, Carstone, and nodule beds at the base of the Gault Clay: 1) glauconitic sands of Early Albian age (mammillatum Biozone) at the base of the Gault in the western outcrop of Lower Cretaceous strata in Wiltshire and Buckinghamshire overlap onto Kimmeridge Clay; 2) The Car-

\begin{tabular}{|c|c|c|}
\hline TEXEL GREENSAND MEMBER & TEXEL CHALK FORMATION & CENOMANIAN \\
\hline UPPER HOLLAND MARL MEMBER & & ALBIAN \\
\hline MIDDLE HOLLAND SHALE MEMBER & HOLLAND FORMATION & \\
\hline HOLLAND GREENSAND MEMBER & & APTIAN \\
\hline LOWER HOLLAND MARL MEMBER & & APIAN \\
\hline
\end{tabular}

Fig. 4. Diagram to show the lithostratigraphic members of the Holland Formation (Dutch southern North Sea) (from N.A.M. \& R.G.D., 1980). 


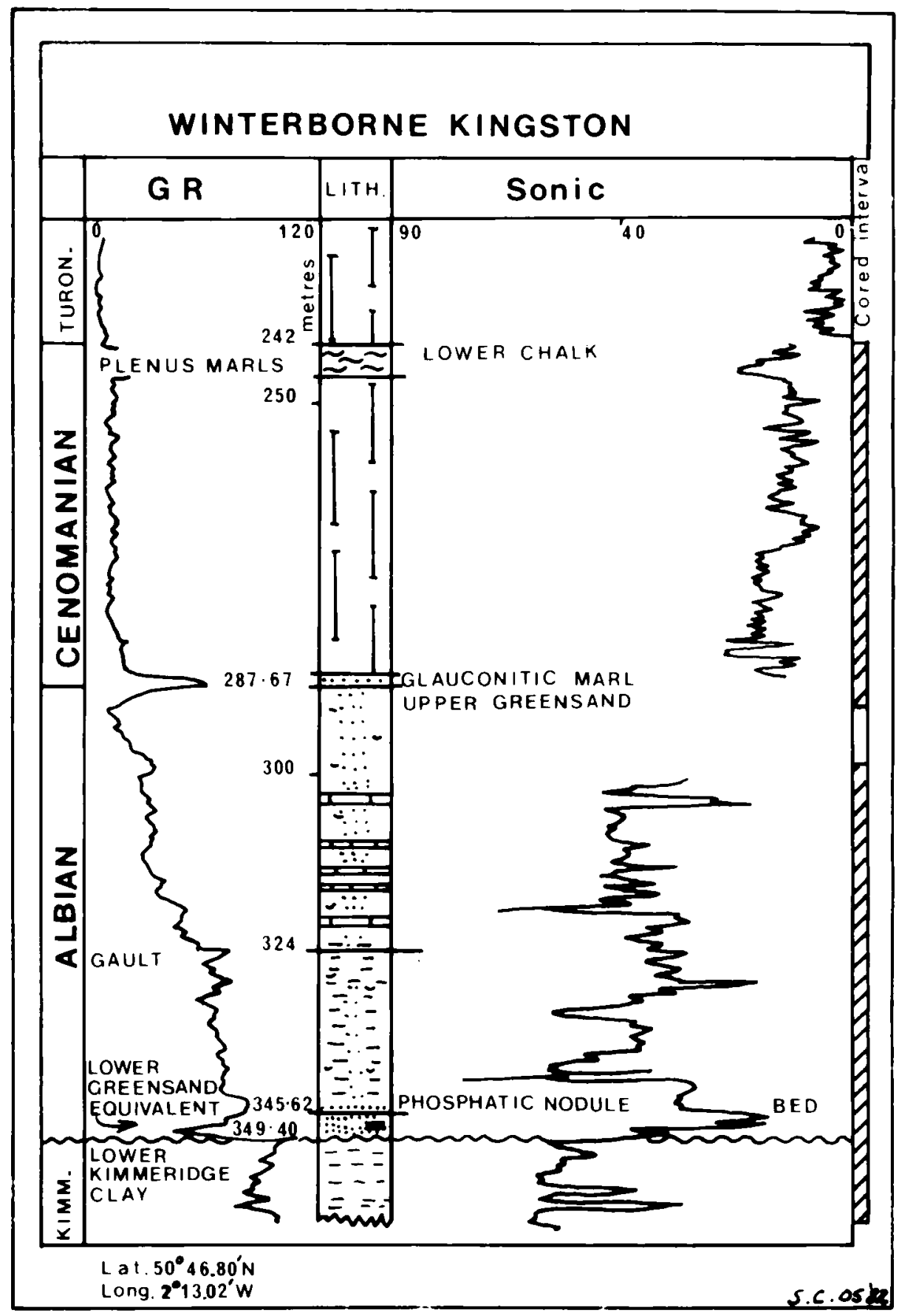

Fig. 5. Lithostratigraphy and electric log character of the Early Cretaceous strata of the Winterborne Kingston Borehole (from Rhys et al., 1982).

stone of the Isle of Wight (mammillatum Biozone), which has a gradational junction with the overlying Gault Clay.

This important transgressive episode is represented north of the London-Brabant Platform: 1) in Yorkshire (Speeton) by the Greensand streak (regularis Subzone of the tardefurcata Biozone; Dilley, 1969; Owen et al., $1968 ; 2)$ in central and southern Lincolnshire by the
Carstone Grit or pebbly base of the Red Chalk where the grit is absent (Owen et al., 1968; Owen, 1972; Rawson et al., 1978). The Gault Clay is the earliest Mesozoic unit known to extend across the Palaeozoic London-Brabant Platform (Owen, 1971a, b), see Fig. 6.

Morter (1982) regards the basement beds of the Lower Gault Clay in the Winterborne Kingston bore- 

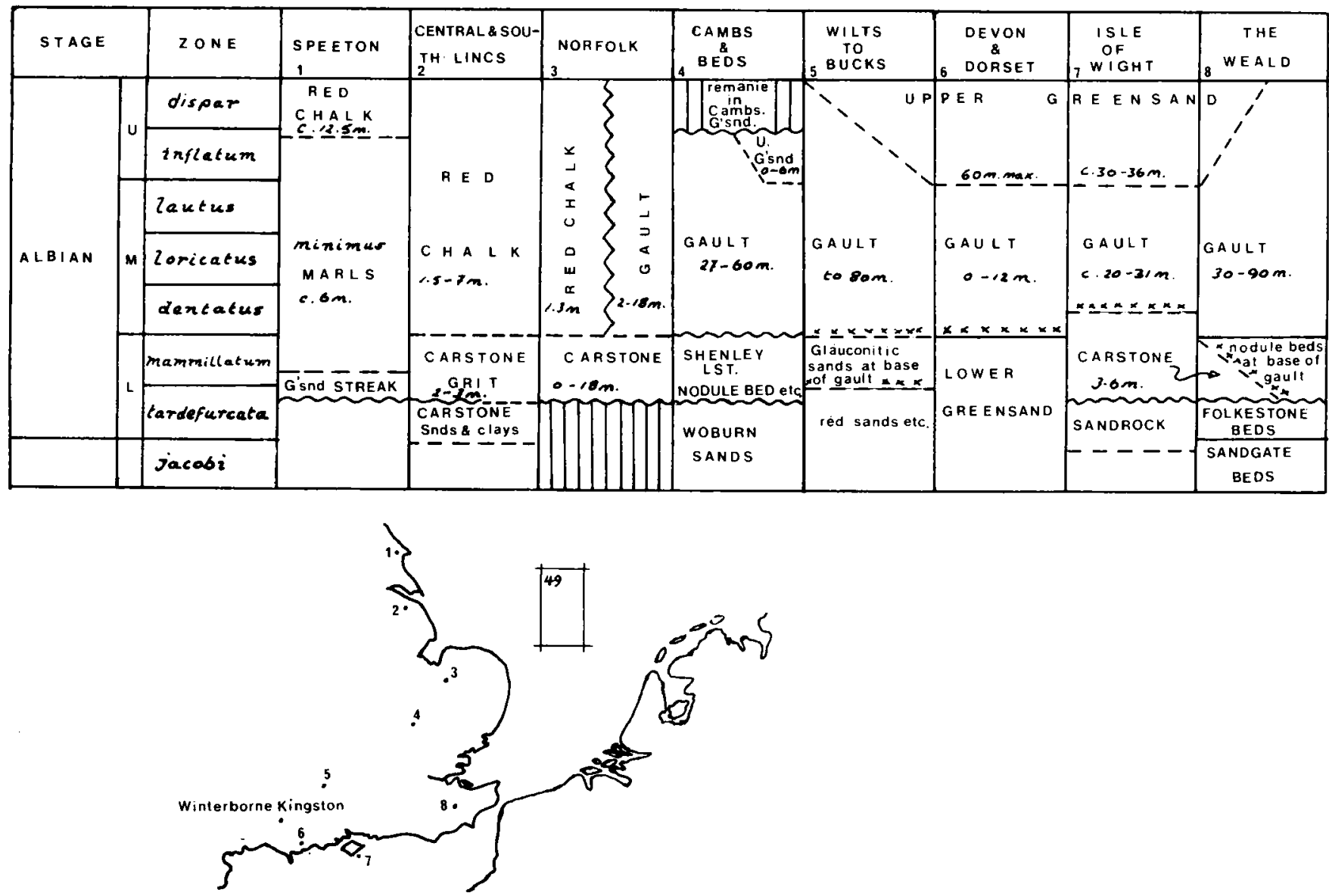

Fig. 6. A correlation of Albian strata across southern and east central England (from Rawson et al., 1978).

hole to be mammillatum Biozone in age (345.24$345.55 \mathrm{~m}$ ) with earlier Albian (kitchini Subzone), and perhaps Late Aptian, greensands beneath. The ostracod data (Wilkinson, 1982) from this borehole is inconclusive with regard to the age of the Early Cretaceous sediments above the Lower Kimmeridgian.

The "sub" Gault Clay transgressive episode may be directly correlated to the "basal" Albian event seen in borehole 49/24-1 (depth c. 4,420ft) and other boreholes in the southern North Sea Basin (N.A.M. and R.G.D., 1980). The transgression is marked by "coastal onlap" at the basin margin but as is seen for borehole 49/24-1 the effects can be traced into basinal areas. Here silty sand and/or, phosphatic-nodule horizons represent erosional periods.

The Lower Gault Clay lies above the Lower Greensand in the Winterborne Kingston borehole. This dark blue/grey-green, silty, calcareous and fossiliferous Early to Middle Albian mudstone/claystone is reputedly a low energy environment deposit laid down away from the major source of supply of clastic terriginous material (Gallois \& Morter, 1982). The electric log pattern of this unit correlates in a broad sense with the Middle Holland Shale Member in borehole 49/24-1 (also with borehole L5-1 (N.A.M.); N.A.M. \& R.G.D., 1980). However, in borehole 49/24-1 the Gault Clay equivalent (Middle Holland Shale Member; Early-Middle Albian in age) is a mottled reddish-grey colour which heralds the colouration of the overlying Upper Holland Marl Member (Red Chalk Formation).

In the Winterborne Kingston borehole the Lower Gault Clay grades upwards through siltstones to a sequence of colourless, white, medium-coarse, very glauconitic sandstones, alternately hard and friable according to the degree of calcite cementation. This Upper Greensand is assumed to be the lateral equivalent of the Red Chalk Formation/Upper Holland Marl Member and the Upper Gault Clay. The coeval relationship of these three units has been demonstrated by various authors (e.g. Carter \& Hart, 1977; Gallois \& 
Morter, 1982) and is summarised by Rawson et al. (1978) (see Fig. 6).

The Upper Greensand is a basin margin deposit (glauconitic marginal shelf sand) as indicated by its outcrop pattern around the perimeter of the Lower Cretaceous depositional basin in south and west England. It accumulated at or about the base of wave effectiveness around the basin margin. The Red Chalk Formation sensu structo is an intensely bioturbated, argillaceous limestone and onshore U.K. is a highly condensed deposit. The Red Chalk Formation passes laterally, when traced southward in Norfolk (Rawson et al., 1978), into rhythmic Upper Gault Clay sediments that initially thicken southwards and then thin as the LondonBrabant Platform is approached and overstepped (Gallois \& Morter, 1982).

The Lower Greensand, Gault Clay, Red Chalk and Upper Greensand succession in southern and central England is far from being a complete unbroken sequence of Early to Late Albian sediments (Price, 1977b). There are numerous minor unconformities, planes of erosion, non-sequences and facies changes (Owen, 1971a, b, 1975, 1979; Gallois \& Morter, 1982). These are a result of such factors as local and regional tectonism, sea bed relief, current scour and sea level changes. This is also true for Albian sediments in other areas of north west Europe (Price, 1977b, Kemper, 1973; Rawson \& Riley, 1982). It is therefore prudent to bear in mind this onshore situation when assessing the stratigraphy of Albian strata in boreholes in the southern North Sea Basin. However, these minor unconformities recognised onshore U.K. are not easily recognised offshore especially when dealing with ditch cutting samples. Further research in progress on other boreholes from block 49 , with closer sample interval, has already demonstrated that the Upper Holland Marl (Red Chalk Formation) - Middle Holland Shale (Speeton Clay (pars.)) formational boundary is a transgressive event (see N.A.M. \& R.G.D., 1980; Rawson \& Riley, 1982).

\section{CONCLUSION}

From a regional point of view the pragmatic approach of constructing a lithostratigraphy and then dating each unit biostratigraphically is sufficient to provide a broad correlation of Lower Cretaceous strata in the southern North Sea (N.A.M. \& R.G.D., 1980; Crittenden, 1982) and onshore U.K. (e.g. Winterborne Kingston borehole).

This approach for an initial analysis is necessarily simplistic. It does involve the integration of various stratigraphical data e.g. electric logs and lithology logs of boreholes both onshore and offshore, plus lithological and biostratigraphical (macrofauna and microfauna) outcrop data (field and literature) and, if available, seismic sections.
This method highlights particular stratigraphical horizons where collection and analysis of additional data would be required before a complete picture or detailed stratigraphical model could be constructed.

In the case of borehole 49/24-1 polyphase condensation during the late Early Cretaceous (Late AptianAlbian), as is shown onshore (Owen, 1971a, b, 1975, 1979; Price, 1977a, b; Rawson \& Riley, 1982), plus inadequate sample coverage makes it difficult to subdivide precisely the Albian strata, to determine hiatus levels or to determine with certainty the presence of Aptian strata.

It is concluded that in borehole 49/24-1 Triassic strata (dated by Shell U.K., pers. comm.) are overlain unconformably by thin Late Aptian sediments which are overlain unconformably by Early to middle Albian sediments and which in turn are overlain (? unconformably) by Late Albian sediments. Further detailed analysis in progress) of late Early Cretaceous strata in adjacent boreholes may resolve the finer stratigraphical details of the Lower Cretaceous in borehole 49/24-1.

\section{ACKNOWLEDGEMENTS}

This research was carried out during the tenure of a C.A.S.E. award with the Natural Environment Research Council and Shell U.K. Exploration and Production Ltd., under the supervision of Prof. Malcolm B. Hart at Plymouth Polytechnic. I am grateful to Shell U.K. and Esso (U.K.) for the provision of borehole material. I would like to thank the following for helpful discussion, provision of reprints of their published work and for their critical comments regarding this research; Miss Kim C. Ball (I.G.S., Leeds), Prof. M. B. Hart (Plymouth Polytechnic), Dr. Haydon W. Bailey (Paleoservices Ltd.), Mr. Tony King (Paleoservices Ltd.), Dr. Tim Burnhill (B.P. Exploration, The Hague) and Dr. Colin S. Harris (Robertson Research, Singapore). 


\section{REFERENCES}

Bartenstein, H. 1965. Taxionomische Revision und Nomenklator zu Franz E. Hecht - Standard Gliederung der Nordwestdeutschen Unter-Kreide nach Foraminifera - 1938. Teil 4, Albian. Senckenberg. leth., Frankfurt, 46, 4-6, 327-366.

Bartenstein, H. 1976a. Foraminiferal zonation of the Lower Cretaceous in north-west Germany and Trinidad, West Indies-an attempt. Neues Jb. Geol. Palaont. Mh, Stuttgart, 3, 187-191.

Bartenstein, H. 1976b. Practical applicability of a zonation with benthonic foraminifera in the worldwide Lower Cretaceous. Geol. Mijnbouw, 54 (1-2), 83-86.

Bartenstein, H. 1976c. Benthonic index Foraminifera in the Lower Cretaceous of the northern hemisphere between East Canada and north-west Germany. Erdol u. Kohle, Erdgas, Petrochemie, 29/6, 254-256.

Bartenstein, H. 1977. Stratigraphic parallelisation of The Lower Cretaceous in the Northern hemisphere. Zonation with benthonic index foraminifera. Newsl. Stratigr., Stuttgart, $6(1), 30-41$.

Bartenstein, H. 1978a. Paleontological zonation. Parallelisation of The Lower Cretaceous Stages in North-west Germany with index ammonites and index microfossils. Erdol $u$. Kohle, Erdgar, Petrochemie, 31/2, 65-67.

Bartenstein, H. 1978b. Phylogenetic sequences of Lower Cretaceous benthic foraminifera and their use in biostratigraphy. Geol. Mijnbouw, 57 (1), 19-24.

Bartenstein, H. 1979. Worldwide zonation of the Lower Cretaceous using benthonic foraminifera. Newsl. Stratigr., Stuttgart, 7 (3), 142-154.

Burnhill, T. J. \& Ramsay, W.V. 1981. Mid-Cretaceous Palaeontology and Stratigraphy, Central North Sea. In Illing, L.V. \& Hobson, G.D. (Eds.), Petroleum Geology of the Continental Shelf of North-west Europe. Institute of Petroleum, London, 245-254.

Carter, D. J. \& Hart, M. B. 1977. Aspects of mid-Cretaceous stratigraphical micropalaeontology. Bull. Br. Mus. Nat. Hist., London (Geol.), 29, 1-135.

Crittenden, S. 1982. Lower Cretaceous lithostratigraphy N.E. of the Sole Pit area in the U.K. southern North Sea. Journ. Petroleum Geol., London, 5, 2, 191-201.

Crittenden, S. 1983. Osangularia schloenbachi (Reuss, 1863): an index foraminiferid species from the Middle Albian to Late Aptian of the Southern North Sea. N. Jb. Geol. Paläont. Abh., Stuttgart, 167 (1), 40-64.

Day, G. A., Cooper, B.A., Andersen, C., Burgers, W.F. T., Rønnevik, H.C. \& Schoneich, H. 1981. Regional Seismic Structure Maps of the North Sea. In Illing, L. V. \& Hobson, G. D. (Eds.). Petroleum Geology of the Continental Shelf of North-west Europe. Institute of Petroleum, London, 76-84.

Dilley, F.C. 1969. The foraminiferal fauna of the Melton Carstone. Proc. Yorks. geol. Soc., Leeds, 37, 321-322.

Gallois, R.W. \& Morter, A. A. 1982. The stratigraphy of the Gault of East Anglia. Proc. Geol. Ass., London, 93 (4), 351-368.

Glennie, K.W. \& Boegner, P. L.E. 1981. Sole Pit Inversion Tectonics. In Illing, L.V. \& Hobson, G. D. (Eds.)., Petroleum Geology of the Continental Shelfof N.W. Europe. Institute of Petroleum, London, 110-120.

Grabert, B. 1959. Phylogenetische Untersuchungen on Gaudryina und Spiroplectinata (Foram.) besonders aus dem nordwest-deutschen Apt und Alb. Abh. senckenb. naturf. Ges., Frankfurt, 498, 1-71.
Harris, C. S. 1982. Albian microbiostratigraphy (foraminifera and Ostracoda) of S.E. England and adjacent areas. Vol. 1, 1-317; Vol. 2, 318-484; Unpub. Ph.D. Thesis, Plymouth Polytechnic.

Hart, M. B. 1973. A correlation of the macrofaunal and microfaunal zonations of the Gault Clay in southeast England. In: The Boreal Lower Cretaceous (Eds.), R. Casey \& P. F. Rawson, Seel House Press, Liverpool, 267-289.

Hart, M. B., Bailey, H. W., Fletcher, B., Price, R. \& Sweicicki, A. 1981. Cretaceous. In Jenkins, D. C. \& Murray, J. W. (Eds.), Stratigraphical atlas of fossil foraminifera, Ellis Horwood Ltd., Chichester for British Micropalaeontological Society.

Kemper, E. 1973. The Aptian and Albian stages in northwest Germany. In Casey, R. \& Rawson, P. F. (Eds.), The Boreal Lower Cretaceous, 360, Seel House Press, Liverpool.

Hecht, F. E. 1938. Standard Gliederung der Nordwestdeutschen Unter Kreide nach Foraminifera. Abh. Senckenb. naturforsch. Ges., Frankfurt, 443, 1-42.

Magniez-Jannin, F. 1975. Les Foraminiferes de l'Albien de l'Aube: Paleontologie, stratigraphie, ecologie. Cahiers de Paleontologie C.N.R.S. Paris, 1-360, 24 pls.

Morter, A. A. 1982. The macrofauna of The Lower Cretaceous Rocks of the Winterborne Kingston borehole, Dorset, pp. 35-38. In Rhys, G.H., Lott, G.K. \& Calver, M.A. (Eds.), The Winterborne Kingston borehole, Dorset, England. Rep. Inst. Geol. Sci., London, No. 81/3.

Nederlandse Aardolie Maatschappij (N.A.M.) \& Rijks Geologische Dienst (R.G.D.) 1980. Stratigraphic nomenclature of the Netherlands. Verh. van het Koninklijk Ned. Geologische Mijnbouwkundig genootschap. 77 pp. +36 enclosures. The Hague.

Owen, E. F., Rawson, P.F. \& Whitham, F. 1968. The Carstone (Lower Cretaceous) of Melton, East Yorkshire, and its brachiopod fauna. Proc. Yorks. Geol. Soc., Leeds, 36/4, 513-524.

Owen, H.G. 1971a. Middle Albian stratigraphy in the AngloParis Basin. Bull. Br. Mus. Nat. Hist., London, (Geol.), Suppl. 8, 1-164, pls. 1-3.

Owen, H. G. 1971b. The stratigraphy of the Gault in the Thames Estuary and its bearing on the Mesozoic Tectonic History of the area.Proc. Geol. Ass., London, 82, 187-207.

Owen, H. G. 1972. The Gault and its junction with the Woburn Sands in the Leighton Buzzard area, Bedfordshire and Buckinghamshire. Proc. Geol. Ass., London, 83, 287-312.

Owen, H.G. 1975. The stratigraphy of the Gault and Upper Greensand of the Weald. Proc. Geol. Ass., London, 86, 475-98.

Owen, H.G. 1979. Ammonite Zonal Stratigraphy in the Albian of North Germany and its setting in the Hoplitinid Faunal Province. Aspekte der Kreide Europas IUGS Series, Stuttgart, A, No. 6, 563-588.

Price, R. J 1977a. The stratigraphical zonation of the Albian sediments of north-west Europe, as based on Foraminifera. Proc. Geol. Assoc., London, 88, 65-91.

Price, R.J. $1977 \mathrm{~b}$. The evolutionary interpretation of the Foraminifera Arenobulimina, Gavelinella, and Hedbergella in the Albian of north-west Europe. Palaeontology, London, 20, 503-527.

Rawson, P.F., Curry, D., Dilley, F.C., Hancock, J. M., Kennedy, W. J., Neale, J. W., Wood, C. J. \& Worssam, B. C. 1978. A correlation of the Cretaceous rocks of the The British Isles. Geol. Soc. Lond. Spec. Rep. 9, 70 pp.

Rawson, P.F. \& Riley, L. A. 1982. Latest Jurassic-Early Cretaceous events and the "Late Cimmerian unconformity" 
in the North Sea Area. Bull. Am. Assoc. Petr. Geol., Tulsa, 66, 2628-2648, 18 figs.

Rhys, G.H. 1974. (Compiler). A proposed standard lithostratigraphic nomenclature for the southern North Sea and an outline structural nomenclature for the whole of the (U.K.) North Sea. A report of the joint Oil Industry-Institute of Geological Sciences Committee on North Sea Nomenclature. Rep.Inst. geol. Sci., eol. Sci., London, No. 73/8, 14 pp.

Rhys, G.H. 1975. A proposed standard lithostratigraphic Nomenclature for the southern North Sea. In Woodland, A. W. (Ed.) Petroleum and the Continental Shelf of N.W. Europe. Vol. 1, Geology, 151-162, London.

Robaszynski, F. \& Caron, M. 1979. Atlas of Mid-Cretaceous planktonic Foraminifera (Boreal Sea and Tethys). Cah. Micropaleont., Paris, Part 1, 1-185, Part 2, 1-181.

Wilkinson, I.P. 1982. Lower Cretaceous to Upper Jurassic Ostracoda from the Winterborne Kingston borehole, Dorset. pp. 39-44, in Rhys, G. H., Lott, G. K. \& Calver, M. A. (Eds.). The Winterborne Kingston borehole, Dorset, England. Rep. Inst. Geol. Sci., London, No. 81/3.

Ziegler, P. A. 1982. Geological Atlas of Western and Central Europe. Shell Internationale Petroleum Maatschappij B. V., pp. 1-130, 40 enclosures. Elsevier Scientific Publishing Co. Amsterdam. 